Artikel Penelitian

Submitted: 18 Juni 2019

Accepted: 26 Juni 2019

Published: 30 Juni 2019

\title{
PENGEMBANGAN MEDIA PEMBELAJARAN SEJARAH BERBANTUAN ISPRING SUITE 6.2 UNTUK MENINGKATKAN HASIL BELAJAR PADA SISWA KELAS XI IPS SMAN 1 SURAKARTA
}

\author{
Sumargono*, Henry Susanto, Valency Rachmedita \\ sumargono.1988@fkip.unila.ac.id \\ Dosen Pendidikan Sejarah, Universitas Lampung
}

\begin{abstract}
This research purpose is the development media historical learning in accordance with the science and technology. One of is the media learning developt, assisted by iSpring Suite 6.2, to improve student learning outcomes. The research method used is the Thiagarajan Research \& Development ( $R \& D$ ) method that study include: 1) Determine, 2) Design, 3) Develop, and 4) Dissemination. Product effectiveness testing was carried out by the experimental method from Senior High School in Surakarta that chosen as the place of investigation. As an experimental group, class XI from social department class 3 was chosen and the class XI social department class 2 was the control group. Based on the analysis by the effectiveness test results. The results of the experimental class after the test (using advanced media), the results of the SPSS 16 analysis were significant at $0,000<0,05$, which means there were significant differences between the experimental class and control class after being treated. Because the average value from the experimental class performance test (subject group on the developed media) $=85.71>$ the average test score of the control class (subject group with powerpoint) $=78.75$, so it can be concluded that effective media has been developed to improve student learning outcomes.
\end{abstract}

Keywords : Media development, iSpring Suite 6.2, Academic achievement

JPSI, Vol. 2, No. 1, 2019 


\section{PENDAHULUAN}

Pendidikan merupakan sesuatu hal yang menjadi prioritas pemerintah dalam mewujudkan pembangunan nasional, sebagaimana tertuang dalam Undang-undang No 20 Tahun 2003 mengenai Sistem Pendidikan Nasional. Berdasarkan undang-undang tersebut, pendidikan nasional bertujuan untuk mengembangkan kemampuan dan membentuk watak serta perdaban bangsa yang bermartabat dalam rangka mencerdaskan kehidupan bangsa, berkembangnya potensi peserta didik agar menjadi manusia yang beriman dan bertakwa kepada Tuhan Yang Maha Esa, berakhlak mulia, sehat, berilmu, cakap, kreatif, mandiri, dan menjadi warga Negara yang demokratis serta bertanggung jawab.

Pembelajaran sejarah nasional yang memiliki kedudukan penting sebagai mata pelajaran pembangun karakter dan sikap nasionalisme siswa saat ini menghadapi banyak persoalan. Persoalan itu mencakup lemahnya penggunaan teoari, miskinya imajinasi, acuan buku teks dan kurikulum yang state oriented, serta kecenderungan untuk tidak memperhatikan fenomena glolablisasi berikut latar belakang historisnya (Subakti, 2010). Pembelajaran sejarah sering dianggap sebagai mata pelajaran hafalan dan pelajaran yang membosankan. Pembelajaran ini dianggap tidak lebih dari rangkaian angka tahun dan urutan peristiwa yang harus diingat kemudian diungkap kembali saat menjawab soal-soal ujian. Kenyataan ini tidak dapat dipungkiri, karena masih terjadi sampai sekarang.

Malik (dalam Rizal, dkk., 2016: 166) menyatakan bahwa keberhasilan dalam pendidikan tidak terlepas dari peran seorang guru dalam membina dan membimbing anak didiknya. Bagian terpenting dalam pembelajaran bahwa proses mengajar adalah bagaimana guru melakukan refleksi terhadap cara mengajarnya agar lebih baik Maka berdasarkan fenomena tersebut dari sekian rangkaian proses pembelajaran sejarah jelas ada sesuatu yang salah, pengamatan kami terhadap proses pembelajaran sejarah pada siswa SMA ditemukan data bahwa sebagian siswa memiliki hasil belajar yang rendah. Menurut Dimyati dan Mudjiono (2013: 3) menyatakan bahwa hasil belajar adalah hasil dari suatu interaksi tindak belajar dan tindak mengajar. Dari sisi guru, tindak mengajar diakhiri dengan proses evaluasi hasil belajar. Dari sisi siswa, hasil belajar merupakan berakhirnya penggal dan puncak proses belajar. Menurut pendapat Hutabarat (1995:11-12), hasil belajar dibagi menjadi empat golongan yaitu : pengetahuan, kemampuan, kebiasaaan 
dan keterampilan serta sikap, yaitu dalam bentuk apresiasi, minat, pertimbangan dan selera.

Hasil belajar merupakan suatu hal yang dibutuhkan siswa untuk mengetahui kemampuan yang diperolehnya dari suatu kegiatan yang disebut belajar. Selain itu berdasarkan pengamatan dan wawancara dengan guru dan siswa mata pelajaran Sejarah di SMAN 1 Surakarta pada 11 Agustus 2016, peneliti menemukan bahwa selama ini metode pembelajaran yang digunakan masih berpusat pada metode ceramah, yakni guru mernberikan penjelasan secara verbal, meskipun sebenarnya bisa dilakukan dengan menerapkan metode lainnya. Media pembelajaran kurang dimanfaatkan guru sejarah di SMAN 1 Surakarta sehingga dalam menyampaikan pelajaran sejarah kurang menarik bagi peserta didik. Guru mata pelajaran sejarah juga belum menggunakan variasi media, bahkan power point juga jarang digunakan sehingga menyebabkan rendahnya minat belajar, motivasi belajar serta hasil belajar siswa.

Lahirnya perkembangan dan teknologi dalam dunia pendidikan diharapkan mampu meningkatkan efektivitas dan efisiensi sekaligus mengatasi masalah-masalah proses pembelajaran seperti proses pembelajaran yang bersifat pasif karena tidak adanya interaksi pembelajaran yang efektif. Selain itu deskripsi mengenai hasil belajar yang rendah disebabkan karena siswa masih ketergantungan terhadap guru, rendahnya untuk menambah wawasan dari berbagai sumber, belajar masih sistem kebut semalam, rendajnya minat membaca dan kurangnya pemanfaatan perpustakaan (Basuki, 2014: 345).

Pesatnya perkembangan zaman dan kemajuan teknologi member kemudahan seseorang dalam mengemas dan menyajikan informasi, demikian pula dalam proses belajar mengajar. Malik \& Agarwal (dalam Lovandri Dwanda Putra, 2018:47) menjelaskan bahwa multimedia yang digunakan pada arah yang benar juga menyukseskan perkembangan psikomotorik dan memperkuat proses visual para pemakai. Salah satu produk teknologi yang dapat digunakan sebagai inovasi dalam pembelajaran adalah komputer. Hal tersebut sesuai dengan pernyataan Herman Dwi Surjono (1995:2) bahwa komputer sebagai salah satu produk teknologi dinilai tepat digunakan sebagai alat bantu pengajaran. Salah satu media pembelajaran sekarang ini yang bisa dikembangkan adalah dengan memanfaatkan teknologi komputer, terutama dalam bidang perangkat lunak yang semakin pesat ini sangat mendukung dalam penerapanya sebagai media pembelajaran yakni Ispring Suite 6.2 . 
ISpring Suite 6.2 merupakan software yang dapat mengubah file presentasi menjadi bentuk flash dan secara mudah dapat diintegrasikan dalam Microsoft PowerPoint sehingga penggunaannya tidak membutuhkan keahlian yang rumit. ISpring Suite menyatukan produk profesional untuk menciptakan program e-learning yang efektif, serta kuis dan interaksi yang akrab di lingkungan PowerPoint. ISpring Suite memastikan integrasi yang erat dengan iSpring QuizMaker dan iSpring Kinetics untuk menciptakan interaksi visual dan daya tarik di luar fungsi dasar PowerPoint (diunduh dari http://www.ispringsolutions.com).

Kelebihan lain yang dimiliki program Ispring Suite 6.2 adalah mampu membuat soal-soal uji kompetensi yang memiliki kelebihan jika digunakan akan selalu mengacak nomor-nomor soal dan option jawaban yang ada antara user yang satu dengan user yang lainnya seperti soal-soal yang diterapkan dalam Ujian Nasional ataupun Tes CPNS saat ini. Jadi soal-soal yang dihasilkan dari pengembangan menggunakan softwer Ispring Suite 6.2 sangat cocok jika digunakan sebagai soal ulangan pada saat ini yang dapat menekan kecurangan dari peserta didik jika ingin kerja sama dengan siswa lain saat mengerjakan ulangan. Selain itu denganlspring Suite 6.2, file dapat dikonversi dan dipublikasikan (publish) ke dalam file aplikasi (exe) maupun dipublikasikan ke jaringan internet melalui Blog yang dimiliki oleh guru pengampu.

Berdasarkan pertimbangan-pertimbangan di atas, peneliti menganggap bahwa permasalahan mengenai media pembelajaran materi masa pendudukan Jepang di Indonesiadalam meningkatkan hasil belajar siswa perlu untuk diteliti lebih lanjut. Adapun tujuan dari penelitian ini yakni untuk mengetahui media pembelajaran sejarah yang digunakan selama ini pada kelas XI IPS SMAN 1 Surakarta, Untuk mengetahui prosedur pengembangan media pembelajaran sejarah berbantuan Ispring Suite 6.2 untuk siswa kelas XI IPS SMAN 1 Surakarta serta untuk mengetahui keefektifan pembelajaran dengan menggunakan media pembelajaran sejarah Ispring Suite 6.2 untuk meningkatkan hasil belajar siswa kelas XI IPS SMAN 1 Surakarta.

\section{METODE PENELITIAN}

Metode yang digunakan dalam penelitian ini yakni metode penelitian pengembangan. Borg and Gall (dalam Sugiyono, 2011: 4) menyatakan bahwa penelitian pengembangan adalah suatu proses yang digunakan untuk mengembangkan dan memvalidasi 
produk-produk yang digunakan dalam pendidikan dan pembelajaran. Dalam penelitian ini menggunakan model penelitian dan pengembangan model Thiagarajan, adapun langkah-langkah untuk mengembangkan media pembelajaran berbasis komputer terdiri dari4 tahap pengembangan yaitu Define, Design, Develop, dan Disseminate atau diadaptasikan menjadi model 4-D, yaitu pendefinisian, perancangan, pengembangan, dan penyebaran (Thigarajan, 1974). Penelitian dan pengembangan yang akan dilakukan nanti dapat diharapkan terencana dengan baik dengan adanya model penelitian pengembangan Thiagarajan. Sehingga dengan suatu perencanaan yang baik maka akan diperoleh hasil penelitian pengembangan yang baik pula untuk memproduksi suatu produk media pembelajaran yang akan dikembangkan.

Subjek yang digunakan dalam penelitian ini adalah siswa kelas XI SMAN 1 Surakarta dan Guru sejarah di SMAN 1 Surakarta serta Kepala sekolah atau Wakil Kepala Sekolah SMAN 1 Surakarta. Selain itu dalam penelitian ini akan menggunakan beberapa teknik pengumpulan data yakni observasi, survei, studi dokumen, wawancara, validasi ahli, respon pengguna, dan tes kemampuan hasil belajar siswa. Kemudian teknik analisis data yang digunakan yakni pengolahan data penelitian pendahuluan, pengujian keefektifan media melalui kuasi eksperimen.

\section{HASIL DAN PEMBAHASAN}

\section{Define (Studi pendahuluan)}

\section{Analisis Permasalahan}

Kendala yang yang sering dihadapi guru dalam pembelajaran sejarah di sekolah yakni: Pertama ${ }_{\iota}$ yang dihadapi oleh guru di sekolah yaitu materi pembelajaran sejarah sangat padat dan banyak sehingga tidak semua materi yang disampaikan kepada siswa dapat diingat dan dipahami dengan baik. Belajar dengan menggunakan indera ganda (pandang dan dengar) akan memberikan keuntungan bagi siswa, hal ini sesuai dengan pandangan Dale (dalam Azhar Arsyad 2013:13) menggambarkan hasil belajar melalui indra pandang dan dengar sangat menonjol perbedaannya. Dale memperkirakan bahwa perolehan hasil belajar melalui indera pandang sekitar $75 \%$, melalui indera dengar $13 \%$, dan melalui indera lainnya sekitar $12 \%$. Maka dengan adaya media pembelajaran yang 
dilihat, didengar kemudian diamati sekaligus akan memberikan pemahaman siswa terhadap materi yang diajarkan, sehingga menjadikan pembelajaran yang menyenangkan.

Akan tetapi pada realitanya, guru belum memahami arti penting media pembelajaran dalam kelancaran proses pembelajaran dan sebagai penunjang pemahaman siswa terhadap materi ajar sejarah, mereka hanya mengandalkan sumber dan media seperti buku teks dan dengan metode ceramah dan ditambah menggunakan sedikit media berupa slide power point namun dirasa belum maksimal. Hal tersebut disebabkan karena adanya kesulitan yang dialami oleh guru dalam mengembangkan media pembelajaran. Guru-guru belum atau jarang menerima pelatihan mengenai pengembangan media pembelajaran, karena selama ini yang sering dibahas hanya mengenai perangkat dan administrasi dalam pembelajaran.

Kedua, gagasan pengembangan media pembelajaran sejarah berbantuan Ispring Suite 6.2 untuk meningkatkan hasil belajar siswa SMAN 1 Surakarta di dukung oleh guru terhadap tujuan pembelajaran sejarah. Dari perspektif siswa mengungkapkan bahwa selama ini mereka hanya belajar berdasarkan buku teks kemudian dijelaskan oleh guru di depan kelas, siswa hanya mendengarkan dan mencatat penjelasan guru, hal ini menimbulkan kebosanan, mengantuk dan kurangnya ketertarikan peserta didik terhadap pembelajaran sejarah. Begitu juga dengan media pembelajaran yang digunakan oleh guru hanya mengandalkan buku teks dan power point saja pada setiap kali pertemuan, hal ini membuat siswa jenuh dan tidak mempunyai ketertarikan terhadap materi yang diajarkan. Media pembelajaran interaktif berbantuan Ispring Suite 6.2 ini digunakan sebagai media dan sumber belajar yang membantu siswa dalam melihat berbagai film dokumenter perjuangan pada masa pendudukan Jepang di Indonesia kemudian bisa menganalisis berpikir kritis setiap peristiwa dan konflik dengan Jepang. Melalui film-film dokumenter itulah diharapkan dapat meningkatkan motivasi belajar yang mengarah pada peningkatan hasil belajar peserta didik.

\section{Analisis Peserta Didik}

Menurut Sadiman (2002: 99) dalam proses belajar mengajar yang dimaksud dengan kebutuhan adalah kesenjangan antara kemampuan, keterampilan, dan sikap siswa yang diharapkan dengan kemampuan, keterampilan, dan sikap siswa yang sudah merekamiliki. Berdasarkan studi pendahuluan dan observasi awal yang dilakukan oleh peneliti di SMAN 1 Surakarta, ditemukan adanya beberapa permasalahan yang berkaitan 
dengan proses pembelajaran.Permasalahan ditemukan pada materi pelajaran sejarah khususnya pada pembahasan materi Masa Pendudukan Jepang di Indonesia. Siswa kurang bisa memahami dan menganalisis proses interaksi Indonesia-Jepang dan dampak pendudukan militer Jepang terhadap kehidupan masyarakat Indonesia. Proses pembelajaran yang terjadi juga masih menempatkan guru sebagai satu-satunya sumber belajar. Guru dalam menyampaikan materi masih menggunakan metode ceramah. Berdasarkan observasi kepada siswa, mereka merasa jenuh dan bosan sehingga menganggap pelajaran sejarah kurang bisa bermakna bagi siswa.

Pengggunaan pembelajaran sejarah berbantuan Multimedia ini diharapkan dapat membantu, baik bagi siswa maupun guru agar materi yang disampaikan mudah dipahami. Pembelajaran ini akan memberikan contoh yang nyata dalam kehidupan seharihari. Siswa akan lebih tertarik dan termotivasi untuk belajar dan meningkatkan hasil belajar sehingga konsep sejarah bisa bermakna, karena hanya dianggap sebagai mata pelajaran hafalan peristiwa dan angka tahun saja. Setelah mengetahui siswa yang menjadi sasaran program multimedia yang akan disusun, selanjutnya adalah menganalisis karakteristik siswa yang menjadi sasaran dikembangkannya media pembelajaran. Berdasarkan hasil wawancara dengan guru sejarah dan siswa kelas XI IPS di SMAN 1 Surakarta, karakteristik tersebut meliputi:

1. Satu kelas terdiri dari laki-laki dan perempuan.

2. Sudah mampu mengoperasikan komputer/laptop.

3. Memiliki kemampuan intelektual yang beragam.

4. Belajar di kelas klasikal.

5. Siswa keragaman dalam keaktifan dalam proses pembelajaran di dalam kelas, sehingga ada siswa kurang terlibat dalam pembelajaran namun ada pula beberapa siswa yang terlalu dominan.

6. Belum pernah belajar dengan media pembelajaran berbantuan multimedia untuk pelajaran sejarah pokok bahasan Masa Pendudukan Jepang di Indonesia.

\section{Analisis Kompetensi dan PerumusanTujuan Pembelajaran}

Perumusan tujuan pembelajaran dalam pengembangan media pembelajaran berbantuan Ispring Suite 6.2 pada materi Masa Pendudukan Jepang di Indonesia didasarkan pada Kompetensi Dasar pada kurikulum 2013. Kompetensi Dasar yang dijadikan dasar 
adalah "Menganalisis proses interaksi Indonesia-Jepang dan dampak pendudukan militer Jepang terhadap kehidupan masyarakat Indonesia"

\section{Design (Perancangan)}

\section{Penyusunan Acuan Patokan}

Menurut Sihkabuden (1992:42) evaluasi media pembelajaran adalah suatu proses kegiatan untuk menilai relevan tidaknya, baik tidaknya, efektif tidaknya media pembelajaran yang dibuat, dipilih dan digunakan dalam proses kegiatan pembelajaran untuk mencapai tujuan-tujuan pembelajaran tertentu. Pengembangan alat evaluasi sangat dibutuhkan dalam mengembangkan media pembelajaran sejarah yang akan dibuat. Pengukuran pencapaian tujuan pembelajaran perlu dilaksanakan setelah proses belajar-mengajar dilaksanakan. Oleh karena itu perlu disusun alat yang digunakan untuk mengukur tingkat keberhasilan siswa. Jenis evaluasi yang akan digunakan sebagai berikut : data angket dan data tes tulis.

\section{Pemilihan Media Pembelajaran}

Melihat dari analisis kebutuhan, disimpulkan bahwa diperlukan pengembangan sebuah media pembelajaran sejarah yang dapat digunakan dalam proses kegiatan pembelajaran di kelas.Media pembelajaran merupakan salah satu sumber belajar yang digunakan oleh peserta didik untuk melatih siswa mengkontruksi atau mengembangkan pemikirannya dari materi yang ditangkap pada media pembelajaran tersebut kemudian mengimplementasikan atau menghubungkan ke dalam kehidupan mereka.

Seperti media Interaktif Berbasis Ispring Suite 6.2 yang didalamnya memuat media audio visual. Media ini merupakan salah satu media pembelajaran yang bisa digunakan untuk membangun pemahaman siswa terhadap materi yang diajarkan sebagaimana yang dikatakan oleh Levie dan Lentz dalam (dalam Sukiman, 2012:38), khususnya media visual, mengemukakan bahwa media pendidikan memiliki empat fungsi yaitu: fungsi atensi, fungsi afektif, fungsi kognitif, dan fungsi kompensatoris. Fungsi atensi media visual merupakan inti, yaitu menarik dan mengarahkan perhatian peserta didik untuk berkonsentrasi kepada isi pelajaran yang berkaitan dengan makna visual yang ditampilkan atau menyertai teks materi pelajaran.Fungsi kognitif media visual terlihat dari temuan-temuan penelitian yang mengungkapkan bahwa lambang visual atau gambar memperlancar pencapaian tujuan untukmemahami dan mengingat informasi atau pesan yang terkandung 
dalam gambar. Fungsi kompensatoris media pembelajaran terlihat dari hasil penelitian bahwa media visual yang memberikan konteks untuk memahami teks membantu peserta didik yang lemah dalam membaca untuk mengorganisasikan informasi dalam teks dan mengingatnya kembali. Dengan kata lain, media pembelajaran berfungsi untuk mengakomodasikan peserta didik yang lemah dan lambat menerima dan memahami isi pelajaran yang disajikan dengan teks atau disajikan secara verbal.

\section{Pemilihan Format}

Setelah tujuan pembelajaran dan materi sudah dirumuskan, maka langkah selanjutnya adalah tahap pemilihan format media. Dalam pengembangan media pembelajaran sejarah Interaktif berbasis Ispring Suite 6.2 ini sebelum proses produksi dilaksanakan langkah yang harus dilakukan adalah merancang desain multimedia. Pengembangan media pembelajaran harus mengacu pada naskah program media yang telah dibuat sebelumnya yakni Perumusan Spesifikasi Multimedia, Pengembangan Flowchart, Pengembangan Storyboard, Produksi Media serta Rancangan Awal.

\section{Development (Pengembangan /Uji coba dan Implementasi Produk)}

Tahap selanjutnya adalah tahap uji coba oleh ahli materi, dan ahli media pembelajaran.Kemudian dilanjutkan dengan tahap uji coba untuk mengetahui kelayakan media pembelajaran berbantuan Ispring Suite 6.2 berupa Media Interaktif pembelajaran yang dikembangkan ini.Uji coba dilakukan kepada siswa dengan tiga tahapan yakni, uji coba satu-satu, uji coba kelompok kecil, dan uji coba lapangan.

\section{Penilaian Ahli Materi}

Evaluasi dari ahli media dijadikan patokan untuk memperbaiki materi selanjutnya. Validasi ini dilakukan sebelum uji kompetensi, sehingga meminimalisir kesalahan ini pada saat diterapkan dalam proses pembelajaran. Ahli materi dalam media pembelajaran Interaktif berbasis Ispring Suite 6.2 yang dikembangkan adalah Sasmito, S.Pd., guru mata pelajaran Sejarah di SMAN 1 Surakarta. 
Tabel 1. Data Hasil Validasi Ahli Materi

\begin{tabular}{lllllll}
\hline No & Kriteria Penilaian & \multicolumn{3}{l}{ Skala Penilaian } \\
\cline { 3 - 6 } & & 1 & 2 & 3 & 4 & 5 \\
\hline 1. & Penyampaian materi yang runtut & 0 & 0 & 0 & 0 & 1 \\
\hline 2. & Penyampaian materi menarik & 0 & 0 & 0 & 0 & 1 \\
\hline 3. & Kegiatan belajarnya memotivasi belajar & 0 & 0 & 0 & 0 & 1 \\
\hline 4. & Materi menarik & 0 & 0 & 0 & 0 & 1 \\
\hline 5. & Kejelasan bahasa untuk memahami materi & 0 & 0 & 0 & 0 & 1 \\
\hline 6. & Materi mudah dipahami & 0 & 0 & 0 & 0 & 1 \\
\hline 7. & Materi mampu menambah pengetahuan & 0 & 0 & 0 & 0 & 1 \\
\hline 8. & Mudah menggunakan media & 0 & 0 & 0 & 0 & 1 \\
\hline 9. & Ukuran huruf dan tulisan & 0 & 0 & 0 & 0 & 1 \\
\hline 10. & Kombinasi warna & 0 & 0 & 0 & 0 & 1 \\
\hline 11. & Kualitas foto/gambar/video & 0 & 0 & 0 & 0 & 1 \\
\hline 12. & Musik & 0 & 0 & 0 & 0 & 1 \\
\hline & Jumlah & 0 & 0 & 0 & 0 & 12 \\
\hline & Jumlah X Skala penilaian & 0 & 0 & 0 & 0 & 60 \\
\hline & Rerata & 5 & & & \\
\hline & Keterangan & Sangat Baik & & \\
\hline
\end{tabular}

Sumber: Kuesioner Uji Coba Ahli Materi Pembelajaran

Hasil validasi dari ahli media, media pembelajaran ini mempunyai jumlah total nilai 60 bila direrata 5 dan bila dikonversikan berdasarkan skala 5 maka secara keseluruhan dinyatakan sangat baik dan layak diterapkan dalam proses pembelajaran di kelas.

\section{Penilaian Ahli Media Pembelajaran}

Evaluasi produk mediapembelajaran oleh ahli media dilaksanakan untuk memperoleh informasi sebagai masukan revisi kualitas produk. Ahli media yang melakukan validasi atau evaluasi atas produk media pembelajaran Interaktif berbantuan/spring Suite 6.2 adalah Prof. Dr. Nunuk Suryani, M.Pd Ketua Jurusan Magister Teknologi Pendidikan Fakultas FKIP Universitas Sebelas Maret Surakarta.Validasi ahli media meliputi aspek penilaian komunikasi, desain, teknis, dan format tampilan. Hasil evaluasi oleh ahli media berupa nilai dengan menggunakan skala Likert rentang 1 sampai 5.Evaluasi keserasian berupa saran dan atau komentar tentang produk media pembelajaran berbantuan/spring Suite 6.2 yang dikembangkan. 
Tabel 2. Data Hasil Validasi Ahli Media

\begin{tabular}{|c|c|c|c|c|c|c|}
\hline \multirow[t]{2}{*}{ No } & \multirow[t]{2}{*}{ Aspek Penilaian } & \multirow[t]{2}{*}{ Pernyataan } & \multicolumn{4}{|l|}{ Skor } \\
\hline & & & 12 & 3 & 4 & 5 \\
\hline \multirow[t]{5}{*}{1} & Komunikasi & Kemudahan penayangan media & & & $\mathrm{V}$ & \\
\hline & & Logika berpikir & & & & $\mathrm{V}$ \\
\hline & & Interaksi dengan pengguna & & & & $\mathrm{V}$ \\
\hline & & Kejelasan video & & & & $\mathrm{V}$ \\
\hline & & Penggunaan bahasa & & & & $\mathrm{V}$ \\
\hline \multirow[t]{5}{*}{2} & Desain Teknis & Format teks & & & & $\mathrm{V}$ \\
\hline & & Waktu pengalihan gambar & & & & $\mathrm{V}$ \\
\hline & & Kualitas gambar & & & & $\mathrm{V}$ \\
\hline & & Kualitas video & & & $\mathrm{V}$ & \\
\hline & & Kualitas suara & & & & $\mathrm{V}$ \\
\hline \multirow[t]{3}{*}{3} & Format tampilan & Urutan penyajian & & & & $\mathrm{V}$ \\
\hline & & Transisi antar gambar & & & & $\mathrm{V}$ \\
\hline & & Tampilan video & & & & $\mathrm{V}$ \\
\hline \multicolumn{2}{|c|}{ Jumlah } & & & & 2 & 11 \\
\hline \multicolumn{2}{|c|}{ Jumlah X Skor } & & & & 8 & 55 \\
\hline \multicolumn{2}{|c|}{ Jumlah total } & & \multicolumn{4}{|l|}{63} \\
\hline \multicolumn{2}{|c|}{ Rerata } & & \multicolumn{4}{|l|}{4,84} \\
\hline \multicolumn{3}{|c|}{ Keterangan } & \multicolumn{4}{|l|}{ Baik } \\
\hline
\end{tabular}

Sumber: Kuesioner Uji Coba Ahli Media Pembelajaran

Hasil validasi dari ahli media, media pembelajaran ini mempunyai jumlah total nilai 62 bila direrata 4,84 dan bila dikonversikan berdasarkan skala 5 maka secara keseluruhan dinyatakan sangat baik dan layak diterapkan dalam proses pembelajaran dengan revisi sesuai saran ahli media pada tombol navigasi agar mudah dipakai dalam proses pembelajaran.

\section{Penilaian Uji Coba Pada Siswa}

1. Data Uji Coba Satu-satu

Uji coba satu-satu dilakukan terhadap 3 (tiga) siswa kelas XI IPS 3 SMAN 1 Surakarta, dengan kriteria 1 siswa berkemampuan tinggi, 1 siswa berkemampuan sedang, dan 1 siswa berkemampuan rendah. Hasil uji coba satu-satu ini dipaparkan dalam bentuk tabel tanggapan yang memuat skor dan rata-rata skor.Berdasarkan data hasil coba satu-satu, secara keseluruhan dapat disimpulkan bahwa media pembelajaran berbantuan Ispring 
Suite 6.2 yang dikembangkan peneliti adalah Sangat Baik menurut siswa. Hal ini dilihat dari jumlah rata-rata penilaian yang dikonversikan ke dalam data kuantitatif yaitu 4,67. Saran dan revisi produk yang diberikan siswa adalah kombinasi warna tiap slide perlu diperbaiki dalam soal warna agar tampak lebih menarik.

\section{Penilaian Uji Coba Kelompok Kecil}

Uji coba kelompok kecil dilakukan terhadap 9 (sembilan) siswa kelas XI IPS 3 SMAN 1 Surakarta, dengan kriteria 3 siswa berkemampuan tinggi, 3 siswa berkemampuan sedang, dan 3 siswa berkemampuan rendah. Hasil uji coba kelompok kecil ini dipaparkan dalam bentuk tabel tanggapan yang memuat skor dan rata-rata skor.Berdasarkan data hasil coba kelompok kecil, secara keseluruhan dapat disimpulkan bahwa media pembelajaran Interaktif berbantuan Ispring Suite 6.2 yang dikembangkan peneliti adalah Baik menurut siswa. Hal ini dilihat dari jumlah rata-rata penilaian yang dikonversikan ke dalam data kuantitatif yaitu 4,10. Saran dan revisi produk yang diberikan siswa adalah kombinasi warna tiap slide perlu diperbaiki dalam soal warna agar tampak lebih menarik.

\section{Penilaian Uji Coba Lapangan}

Uji coba lapangan berdasarkan masukan dari tinjauan ahli media pembelajaran, ahli materi, uji coba-satu-satu, dan uji coba kelompok kecil, maka pada langkah berikutnya adalah melaksanakan uji coba lapangan terhadap 31 siswa.Hasil uji coba lapangan dipaparkan dalam bentuk table tanggapan yang memuat skor dan rata-rata skor. Berdasarkan data hasil coba lapangan, secara keseluruhan dapat disimpulkan bahwa media pembelajaran Interaktif berbantuan Ispring Suite 6.2 yang dikembangkan peneliti adalah sangat baik menurut siswa. Hal ini dilihat dari jumlah rata-rata penilaian yang dikonversikan ke dalam data kuantitatif yaitu 4,25. Dalam uji coba lapangan bertujuan untuk menentukan apakah penggunaan produk hasil pengembangan memiliki dampak yang positif terhadap hasil pengembangan yang diharapkan dan untuk memperbaiki kualitas produk sehingga produk siap untuk diterapkan dalam lapangan yang lebih luas. 


\section{Keefektifan Media Pembelajaran Sejarah Berbasis Ispring Suite 6.2 di SMAN 1 Surakarta}

\section{Diskripsi Hasil Uji Skala Sikap Kelas Eksperimen dan Kelas Kontrol}

Untuk menguji keefektifan media pembelajaran Interaktif berbantuan Ispring Suite 6.2 yang telah dikembangkan adalah dengan melakukan tes hasil belajar siswa. Untuk melakukan uji kompetensi ini melibatkan dua kelas yaitu kelas yang menggunakan media pembelajaran Interaktif berbantuan/spring Suite 6.2 yang dikembangkan (kelas eksperimen) yaitu pada kelas XI IPS 3 dan kelas yang menggunakan media powerpoint (kelas kontrol) yaitu pada kelas XI IPS 2 SMAN 1 Surakarta. Soal untuk hasil belajar sebanyak 100 butir dan dilaksanakan pada tanggal 10 September 2016. Berdasarkan data perhitungan yang telah dilakukan dapat diketahui bahwa rata-rata skor uji tes hasil belajar kelas eksperimen (kelompok yang dikenai media pembelajaran yang kembangkan) adalah 65,63 pada pre tes dan post tesnya 85,71 . Sedangakan jika dilihat dari kelas kontrol (kelompok yang dikenai media power point) menunjukkan nilai pre tes untuk tes hasil adalah 65,56 dan nilai post tesnya 78,75 .

\section{Uji Keefektifan Media Pembelajaran Sejarah}

Untuk membuktikan efektifitas pemanfaatan produk media pembelajaran Interaktif Berbantuan/spring Suite 6.2 yang dikembangkan dalam meningkatkan prestasi belajar peserta didik maka dilakukan uji t Berikut hasil perhitungan uji t tes:

a. Uji Kesetaraan

Rancangan eksperimen yang digunakan dalam penelitian ini adalah the Matching Only pra test-post test control group design. Konsekuensi dari penggunaan rancangan ini adalah kedua kelompok yang dibandingkan secara statistik harus dalam kondisi yang sama sebelum perlakuan (treatment) diberikan. Untuk mengetahui keadaan awal sebelum perlakuan diberikan (antara eksperimen dan kontrol), dilakukan pemberian pra tes kepada dua kelompok subyek yang akan diberi perlakuan itu. 
Tabel 3. Hasil Independent Samples Test

Independent Samples Test

\begin{tabular}{|c|c|c|c|c|c|c|c|c|c|c|}
\hline & \multicolumn{2}{|c|}{$\begin{array}{l}\text { Levene's Test for } \\
\text { Equality of Variances }\end{array}$} & \multicolumn{7}{|c|}{ t-test for Equality of Means } \\
\hline & & \multirow[b]{2}{*}{$\mathrm{F}$} & \multirow[b]{2}{*}{ Sig. } & \multirow[b]{2}{*}{$t$} & \multirow[b]{2}{*}{ df } & \multirow[b]{2}{*}{ Sig. (2-tailed) } & \multirow{2}{*}{$\begin{array}{c}\text { Mean } \\
\text { Difference }\end{array}$} & \multirow{2}{*}{$\begin{array}{l}\text { Std. Error } \\
\text { Difference }\end{array}$} & \multicolumn{2}{|c|}{$\begin{array}{l}95 \% \text { Confidence } \\
\text { Interval of the } \\
\text { Difference }\end{array}$} \\
\hline & & & & & & & & & Lower & Upper \\
\hline Nilai_Pre & $\begin{array}{l}\text { Equal variances } \\
\text { assumed }\end{array}$ & .031 & .860 & .035 & 62 & .973 & .06250 & 1.80986 & -3.55535 & 3.68035 \\
\hline & $\begin{array}{l}\text { Equal variances } \\
\text { not assumed }\end{array}$ & & & .035 & 62.000 & .973 & .06250 & 1.80986 & -3.55535 & 3.68035 \\
\hline
\end{tabular}

Dari hasil analisis SPSS 16 diketahui signifikan pada 0,973>0,05 yang berarti tidak ada perbedaan yang signifikan antara kelas eksperimen dan kelas kontrol sebelum diberi perlakuan jadi sampel dapat digunakan untuk eksperimen penelitian.

b. Uji Pra Syarat

1) Uji Normalitas

Uji normalitas yang digunakan di sini adalah uji normalitas menggunakan uji-t. Uji ini dilakukan pada suatu variabel yang memiliki dua atau lebih kelompok data. Jadi pengujian ini dimaksudkan untuk mengetahui apakah tiap-tiap kelompok data berasal dari populasi normal atau tidak (Dwi Priyatno, 2008).

Tabel 4. Hasil Tes Normalitas

Tests of Normality

\begin{tabular}{|ll|r|r|r|r|r|r|}
\hline & \multicolumn{3}{|c|}{ Kolmogorov-Smirnov $^{\mathrm{a}}$} & \multicolumn{3}{c|}{ Shapiro-Wilk } \\
\cline { 3 - 8 } & Kelompok & Statistic & \multicolumn{1}{c|}{ df } & \multicolumn{1}{c|}{ Sig. } & Statistic & \multicolumn{1}{c|}{ df } & \multicolumn{1}{c|}{ Sig. } \\
\hline Nilai_Pre & Eksperimen & .129 & 32 & .190 & .947 & 32 & .117 \\
& Kontrol & .126 & 32 & $.200^{\star}$ & .967 & 32 & .413 \\
\hline Nilai_Post & Eksperimen & .119 & 32 & $.200^{\star}$ & .964 & 32 & .353 \\
& Kontrol & .117 & 32 & $.200^{*}$ & .968 & 32 & .452 \\
\hline
\end{tabular}

${ }^{\star}$. This is a lower bound of the true significance.

a. Lilliefors Significance Correction

Penelitian ini menggunakan uji normalitas data dan varians menggunakan uji One Sample Kolmogorov-Smirnov dengan taraf signifikasi 0,05. Data dinyatakan berdistribusi normal jika signifikansi lebih besar dari 5\% atau 0,05 (Dwi Priyatno, 2008). Berdasarkan 
hasil uji normalitas Kolmogorov-Smirnov, sikap nasionalisme menunjukkan taraf signifikansi yang lebih besar dari $\alpha(p>0,05)$, sehingga data tersebut dinyatakan memiliki distribusi normal atau memiliki sebaran data yang normal.

\section{2) Uji Homogenitas}

Uji homogenitas digunakan untuk mengetahui varians populasi sama atau tidak. Uji ini juga merupakan syarat penggunaan uji-t, jika varians populasi tidak sama maka uji-t tidak dapat digunakan sebagai alat analisis. Uji homogenitas digunakan untuk mengetahui apakah data sampel berasal dari populasi yang memiliki variansi yang sama.

Tabel 5. Hasil Independent Samples Test

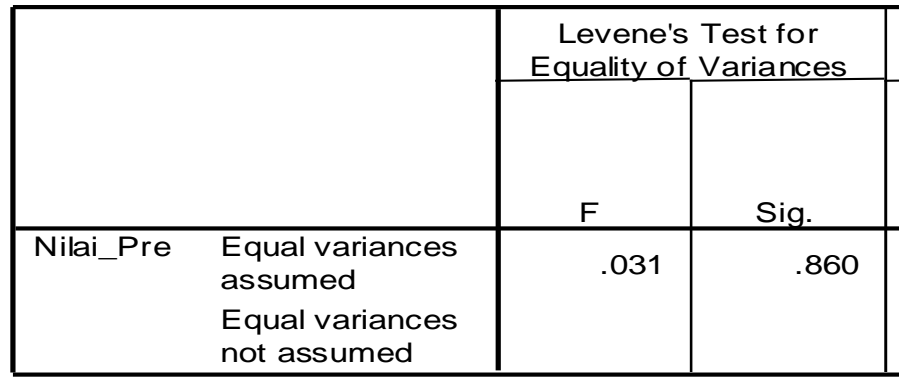

Berdasarkan data perhitungan dapat diketahui bahwa sampel memiliki taraf signifikansi lebih besar dari 0,05 $(0,860>0,05)$. Maka dapat diambil kesimpulan bahwa sampel hasil belajar siswa dari populasi mempunyai variansyang sama (homogen).

c. Uji Hipotesis

Rancangan eksperimen yang digunakan dalam penelitian ini adalah the Matching Only pra test-post test control group design. Penggunaan rancangan ini adalah untuk melihat hasil kedua kelompok yang dibandingkan secara statistik dalam kondisi yang akhir setelah perlakuan (treatment) diberikan. Untuk mengetahui keadaan akhir setelah perlakuan diberikan (antara eksperimen dan kontrol), dilakukan pemberian post tes kepada dua kelompok subyek yang diberi perlakuan yang berbeda yaitu media pembelajaran. Uji Hipotesis pada penelitian ini menggunakan menggunakan Uji-t. 
Tabel 6. Hasil Uji t

Independent Samples Test

\begin{tabular}{|c|c|c|c|c|c|c|c|c|c|c|}
\hline & \multicolumn{2}{|c|}{$\begin{array}{c}\text { Levene's Test for } \\
\text { Equality of Variances }\end{array}$} & \multicolumn{7}{|c|}{ t-test for Equality of Means } \\
\hline & & \multirow[b]{2}{*}{$\mathrm{F}$} & \multirow[b]{2}{*}{ Sig. } & \multirow[b]{2}{*}{$t$} & \multirow[b]{2}{*}{ df } & \multirow[b]{2}{*}{ Sig. (2-tailed) } & \multirow{2}{*}{$\begin{array}{c}\text { Mean } \\
\text { Difference }\end{array}$} & \multirow{2}{*}{$\begin{array}{l}\text { Std. Error } \\
\text { Difference }\end{array}$} & \multicolumn{2}{|c|}{$\begin{array}{l}95 \% \text { Confidence } \\
\text { Interval of the } \\
\text { Difference }\end{array}$} \\
\hline & & & & & & & & & Lower & Upper \\
\hline Nilai_Post & $\begin{array}{l}\text { Equal variances } \\
\text { assumed }\end{array}$ & .490 & .487 & 3.791 & 62 & .000 & 6.96875 & 1.83834 & 3.29395 & 10.64355 \\
\hline & $\begin{array}{l}\text { Equal variances } \\
\text { not assumed }\end{array}$ & & & 3.791 & 60.653 & .000 & 6.96875 & 1.83834 & 3.29233 & 10.64517 \\
\hline
\end{tabular}

Dari hasil analisis SPSS 16 diketahui signifikan pada 0,000<0,05 yang berarti ada perbedaan yang signifikan antara kelas eksperimen dan kelas kontrol setelah diberi perlakuan.Karena rerata nilai tes hasil belajar kelas eksperimen (kelompok yang dikenai media pembelajaran yang dikembangkan) $=85,71>$ rerata nilai tes hasil belajar kelas kontrol (kelompok yang dikenai power point) $=78,75$ sehingga dapat disimpulkan bahwa media yang dikembangkan efektif untuk meningkatkan hasil belajar peserta didik.

Perbandingan rata-rata nilai kelompok yang menggunakan media pembelajaran menggunakan Interaktif berbantuan Ispring Suite 6.2 yang dikembangankan dan kelompok yang menggunakan media power point dapat dilihat pada gambar 1.

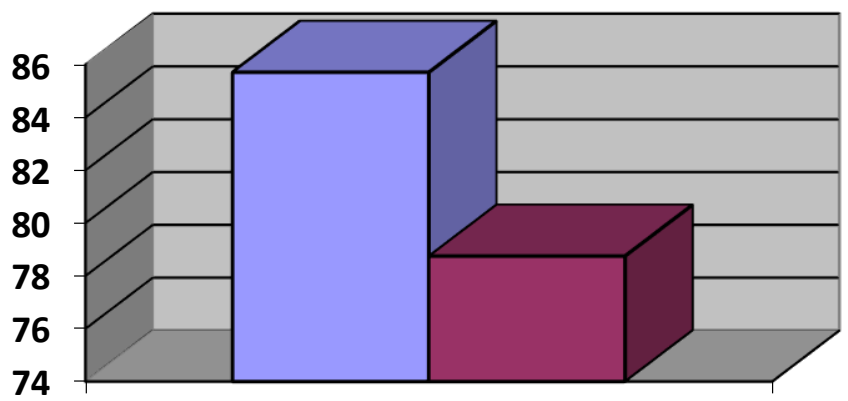

Nilai tes Hasil Belajar Siswa (Post test)

\section{口Kelas \\ Eksperimen}

Gambar 1. Perbandingan Nilai Rata-rata Post Test Kelas Eksperimen dan Kelas Kontrol 


\section{DISSEMINATE (TAHAP PENYEBARAN)}

Tahapan ini pada dasarnya terdiri dari tiga tahapan, namun akan dimodifikasi dengan cara melakukan penyebaran hasil pengembangan media pembelajaran melalui wadah MGMP Sejarah Kota Surakarta pada tanggal 15 September 2016 di Sekolah SMA AL Islam 1 Surakarta. Setelah dirasa berhasil dalam pengembangan produk dan sudah mengalami desiminasi, peneliti berharap produk yang sudah dikembangkan dapat digunakan oleh guru-guru sejarah SMA di Kota Surakarta dalam proses pembelajaran sejarah dan evaluasi soal pada materi Masa Pendudukan Jepang di Indonesia. Selain itu penyebaran juga dilakukan pada bentuk digital melalui website atau email.

\section{KESIMPULAN}

Berdasarkan hasil penelitian dapat disimpulkan: 1) Penggunaan media yang minim dan kurang tepat dengan karakterikstik siswa berdampak pada pembelajaran sejarah yang tidak menarik dan membosankan bagi siswa yang berujung pada hasil belajar sejarahnya menjadi tidak memuaskan. 2) Pengembangan media dilakukan melalui prosedur pengembangan yang dimulai dari perencanaan, produksi media pembelajaran Interaktif berbantuan Ispring Suite 6.2 pembelajaran sejarah, dan validasi. 3) Hasil validasi secara keseluruhan menyatakan bahwa media Interaktif yang dikembangkan layak untuk diproduksi dan dimanfaatkan dalam pembelajaran sejarah .4) Uji implementasi Media Pembelajaran Interaktif dalam pembelajaran sejarah membawa peningkatan dalam prestasi belajar sejarah. Berdasarkan analisis hasil uji kefektifan, hasil post test kelas eksperimen (menggunakan media yang dikembangkan) lebih tinggi dibandingkan dengan kelas kontrol (menggunakan power point). Pernyataan tersebut dibuktikan berdasarkan data dari hasil analisis SPSS 16 diketahui signifikan pada 0,000<0,05 yang berarti ada perbedaan yang signifikan antara kelas eksperimen dan kelas kontrol setelah diberi perlakuan. Karena rerata nilai tes hasil belajar kelas eksperimen (kelompok yang dikenai media pembelajaran yang dikembangkan) $=85,71>$ rerata nilai tes hasil belajar kelas kontrol (kelompok yang dikenai power point ) $=78,75$ sehingga dapat disimpulkan bahwa media yang dikembangkan efektif untuk meningkatkan prestasi belajar peserta didik. Uraian tersebut diatas membuktikan bahwa produk media pembelajaran sejarah menggunakan Media Pembelajaran Interaktif Berbantuan Ispring Suite 6.2 yang dikembangkan efektif untuk meningkatkan hasil belajar peserta didik. 


\section{DAFTAR PUSTAKA}

Arsyad, A.(2013). Media Pembelajaran.Jakarta : Raja Grofindo Persada

Basuki, U. (2014). Perbedaan Pengaruh Penggunaan CD Interaktif dan MS.Power point Terhadap Prestasi Belajar Memperbaiki Sistem Rem Setelah Dikendalikan dari Kemampuan Awal Siswa . Jurnal Teknologi Pendidikan dan Pembelajaran.

Dimyati \& Mudjiono.(2013). Belajar Dan Pembelajaran. Jakarta: Rineka Cipta.

E.P. Hutabarat. (1995). Cara Belajar Sebagai Pedoman Praktis Untuk Belajar Secara Efisien dan Efektif. Penerbit BPK Gunung Agung. Jakarta.

http://www.ispringsolutions.com

Putra, L.D. (2018). Pengembangan Multimedia Pembelajaran Interaktif Pengenalan Pariwisata Lokal Berbasis Macromedia Flash Untuk Siswa Sekolah Dasar Yogyakarta. Jurnal JPSD (Jurnal Pendidikan Sekolah Dasar) Vol.5 No.1 Tahun 2018

Rivai , dkk. (1991). Media Pengajaran . Bandung: CV. Sinar Baru

Rizal, A.S, dkk. (2016).Efektivitas Multimedia Interaktif Flash Pada Pemebelajaran Pendidikan Agama Islam di Sekolah Menengah Pertama. Jurnal Pendidikan Agama Islam-Ta'lim Vol.14 No.2-2016

Sadiman, A. (2002). Media Pendidikan: Pengertian, Pengembangan, Dan Pemanfaatan. Jakarta : Grafindo Pers.

Sihkabuden. (1999). Media Pembelajaran. Jakarta: Depdikbud.

Subakti, Y.K. (2010). Paradigma Pembelajaran Sejarah Berbasis Konstruktivisme. Jurnal SPPS, Vol.24, No.1, April 2010.

Sugiyono. (2011). Metode Penelitian Kuantitatif, Kualitatif dan R\&D. Bandung: Afabeta

Sukiman.(2012). Pengembangan Media Pembelajaran. Yogyakarta : Pedajogja

Surjono, H. D. (1995). Pengembangan Komputer Asissted Intruction (CAI) Untuk Pelajaran Elektronika. Jurnal Kependidikan, (online) No. 2 (XXV) 1995. Tersedia pada http://herman.elearningjogja.org/Pengembangan Program CAl.pdf

Thiagarajan, S., Semmel, D.S \& Semmel, M.I .(1974)..Instructional Development for Training Teachers of Expectional Children. Minneapolis, Minnesota : Leadership Training Institute/Special Education, University of Minnesota.

Undang-undang RI No 20 Tahun 2003 Tentang Sistem Pendidikan Nasional. 